\title{
BÉRES NORBERT
}

\section{„Román, 's mi jobb a' Románnál” \\ - a román népszerüsítésének stratégiáiról ${ }^{*}$}

Jelen dolgozat elsődleges célkitűzése a 18-19. századi románsorozatok kiadásával, propagálásával és értékesítésével kapcsolatos korabeli gyakorlatok rekonstruálása. Közismert, hogy a régi századforduló a magyar nyelvủ széppróza térhódításának, a románok számszerü gyarapodásának kiemelkedő időszaka. ${ }^{1}$ Miközben a keresztény morál primátusát féltő egyházi gondolkodók, ${ }^{2} \mathrm{~s}$ a régi tudós müveltségủ literátorok pálcát törtek a károsnak minősített müfaj fölött, a román minden korabeli tömegnyomtatvány keresettségét és népszerüségét túlszárnyalta. ${ }^{3}$ A kiadványok jelentősen (mondhatni ugrásszerüen) megnövekedő száma ezért szükségessé tette egy következetes finanszírozási és értékesítési rendszer fokozatos kialakítását, a kötetek szélesebb körben való megismertetésére irányuló technikák alkalmazását. ${ }^{4} \mathrm{Az}$ e logika szerint kialakuló szövegtípusok, a „Tudósítás”, a „Jelentés”, a „Híradás”, ${ }^{5}$ később pedig a recenzió jelzik, hogy

* Előadásként elhangzott az Irodalmi nyilvánosság a polgárosodó Nyugat-Magyarországon (1770-1820) Lendület Kutatócsoport (kutatócsoportvezető: Csörsz Rumen István), a Győri Hittudományi Főiskola és a Pannonhalmi Bencés Gimnázium szervezésében rendezett Sajtó és irodalom a többnyelvü Magyarországon (1770-1820) című nemzetközi konferencián (Győr, 2018. április 27.).

${ }^{1}$ Vö. Bíró Ferenc, A felvilágosodás korának magyar irodalma, Bp., Balassi, 1998², 189-222; SzAJBÉLy Mihály, ,Idzadnak a' magyar tollak”, Irodalomszemlélet a magyar irodalmi felvilágosodás korában, a 18. század közepétöl Csokonai haláláig, Bp., Akadémiai-Universitas, 2001 (Irodalomtudomány és Kritika), 159-191; SzILÁGYI Márton, VADERna Gábor, A prózaepika = Magyar irodalom, szerk. Gintli Tibor, Bp., Akadémiai, 2010 (Akadémiai Kézikönyvek), 370-404; BóDI Katalin, Könny és tinta, A magyar levélregény és heroida történeti és poétikai háttere, Debrecen, Egyetemi Kiadó, 2010 (Csokonai Könyvtár, Bibliotheca Studiorum Litterarium, 46).

2 SzaJBÉly 2001, i. m. 185.

3 Fülöp Géza, Olvasási kultúra és könyvkiadás Magyarországon a felvilágosodás idején és a reformkorban (1772-1848), Bp., Hatágú Síp Alapítvány, 2010 (A könyves szakképzés füzetei, 17), 69-71. Vö. KulcsáR Adorján, Olvasóközönségünk 1800 táján, Bp., Királyi Magyar Egyetemi Nyomda, 1943, 60-61.

${ }^{4}$ Vö. KóKAY György, A könyvkereskedelem Magyarországon, Bp., Balassi, 1997, 83-109.

${ }_{5}$ Nincs konszenzus arról, milyen kritériumok szerint lehetne elkülöníteni az egyes hirdetéstípusokat, a megnevezések alkalmazása a kiadók esetében is következetlen. További, kevésbé rendszeres megnevezések a „Tudományos dólgok” (Mindenes Gyüjtemény), „Litteratori Tudósítások” (Orpheus), „Tudománybéli Tudósítás” (Magyar Hírmondó, Magyar Merkurius), „Tudományi Híradások” (Magyar Merkurius), „Tudománybéli Jelentés”, „Tudományt tárgyazó Tudósítás”, „Tudo- 
a propagálás, az előfizetésekre összpontosító tevékenységek kilépnek a nyilvánosságtól elzárt magánszféra keretei közül, s a periodikák felületét felhasználva szélesebb nyilvánosság előtt teszik megismerhetővé a kiadott, vagy kiadás előtt álló kötetek jellemzőit. Minthogy a könyv mint közforgalomba hozott árucikk értékesítésének, ezáltal az olvasókhoz való eljuttatásának szükségessége alapvető fontosságúnak bizonyult a korszak kiadói számára, a felismerés elvezet a korabeli hírlapok, folyóiratok a könyvterjesztés rendszerében betöltött szerepének átrendeződéséhez. Az időszaki kiadványok reklámfelületein megjelenő tudósítások, hirdetések egyrészt hozzájárultak a megjelenő kötetek szélesebb körü megismertetéséhez, a könyvtermék értékesíthetőségének elősegítéséhez, másrészt megteremtették a róluk való diskurzus lehetőségét. ${ }^{6}$ Hogy kontextusában értelmezhessük a régi századforduló népszerủ prózairodalmának térhódítását, irodalomszociológiai szempontok alkalmazásával érdemes közelítenünk a román gyors ütemü felfutásának irodalmi, részben társadalmi jelenségéhez.

Részint mediális eltéréseik következtében, részint hiányosságukból, szétszórtságukból adódóan a forráscsoportok heterogenitása megnehezíti a folyamat rekonstruálását: más funkció betöltésére szánták ugyanis a kötetek paratextusaiban közzétett tudósításokat, mint a hírlapokban publikált felhívásokat. Ezek más-más következtetések megfogalmazására adnak alkalmat. Az előbeszédek alapvetően programos elgondolások szerint, ideologikus toposzok felhasználásával közelítenek olvasóik felé, melyekben csupán áttételesen, a haza szolgálatának éthosza mögé rejtve szerepel a gazdasági célzat. Az erkölcsnevelés ideologikus funkciója és az anyagi haszon között húzódó, a korszakban többek által is hangsúlyozott feszültséget feltételezhetően a kiadók is érzékelték, ezért igyekeztek vállalkozásaikat ideológiai szempontból is megalapozni a tudós hazafiságot, a női olvasóközönséget, vagy a hasznosságot mintázó retorikai klisék alkalmazásával, érveléseikben a közönségért, a literatúráért, a nemzetért folytatott lelkiismeretes, hazafias tevékenységet állítva előtérbe. Csakhogy a kötetek paratextusaiból kiolvasható ideologikus perspektíva mellett már kidomborodnak a pragmatikus, a kötetek konkrét értékesítését célzó, a könyvet immáron üzleti produktumként felfogó megfogalmazások. Az elvont síkon értelmezhető, valamint a konkrét,

mányos Tudósítás” (Magyar Kurír), „Könyvárosi Tudósítás”, „Új Könyvek” (Hazai Tudósítások), „Tudósító Levelek” (Erdélyi Muzéum), „Új Könyvek és Mívek” (Tudományos Gyüjtemény) stb.

${ }^{6}$ Decsy Sámuel szemérmes hangvételü jelentése konkrétan utal e szerteágazó funkcióra: „Mi, mint a' kik a' Magyar Litteraturának nem leg utólsó eszközlői 's gyarapitói lenni kivánunk, jelentjük, 's adjuk a' tudós Magy[ar] Publicumnak tudtára, hogy mi, minden kedves Hazánkban Magyar vagy Deák nyelven ki adatandó hasznos és jó munkákat, ezen újság leveleinkben ki hirdetni mindenkor készen lészünk. Arra való nézve kérjük tudós hazánkfiait, hogy mihelyt egy illy köz hasznú munka a' sajtó alól ki fog szabadúlni, arról vagy magok, vagy mások által tudositsanak bennünket, vagy a' melly még kedvesebb leszen előttünk, munkáikat nékünk meg kủldeni ne sajnálják. Mi, a' kik Polyhistoroknak magunkat nem tartjuk, tartani nem akarjuk, nem is tarthatjuk, az azokról való itilet tételt másnak engedjük; de azomban azt is jó szivvel veszük, ha tudós hazánkfiai az illy új könyvekröl való, minden részre hajlástól üres értelmeket velünk közleni, 's általunk az Olvasó Publícum előtt esméretessé tenni nem sajnállyák.” Magyar Kurír, 1803. aug. 9., 192. 
gyakorlati ismeretekre összpontosító szólamok szintetizálásának kísérletében idővel fokozatos elmozdulás mutatkozik a pragmatikus szemléletmód felé. Míg a paratextusokban az ideologikus célzatosság következetes fenntartása jellemző, a hírlapokban közzétett tudósítások, jelentések, hirdetések a köteteket piaci termékként, értékesítendő áruként jelenítik meg.

\section{„Hasznos Mulatságok” (ideologikum)}

Első forráscsoportként a kötetek paratextusai különíthetők el. Az előszavak orientáló-propagáló funkciójára már Szajbély Mihály kutatásai felhívták a figyelmet, ${ }^{7}$ jelen gondolatmenetben elegendő annak megerősítése, hogy e funkció rendszerint ideologikus megszólalásmódok keretében került kifejezésre. A magyarországi könyvkiadók vélhetően saját üzleti érdekeiket szem előtt tartva jutnak a felismerésre, hogy az olvasóközönség aktuális igényeit megcélzó kiadványok magas példányszámú előállításával lehetőség nyílhat a könyv mint termék tömegcikké tételére. „Különösen kifizetődő vállalkozás a szakosított sorozat, melynek irányítása, külseje és érdeklődési területe azonos. Ez egyrészt a szerzőket kipróbált hatású terméktípusok irányába tereli, másrészt határozott, jól körülhatárolható és élő kívánságot elégít ki. [...] Ebből látszik, hogy minden sorozat mögött van egy feltételezett közönség, amelynek nevében és érdekében a választás történik". 8 Amikor 1798-ban az olvasóközönség románok iránt növekvő érdeklődésére alapozva9 elindul Landerer Ferenc kassai nyomdász vállalkozása, a Rózsa Szín Gyüjtemény, a tizenhárom kötetet kitevő sorozatát „a tisztelt szép Nemnek” ajánlja, hangsúlyozván a női olvasók kitüntetett figyelme és a jövőbeni könyveladás sikeressége közötti áttételes összefüggést: „Ezen tzím alatt: a' Rózsa szín Gyüjtemény különféle erkőltsi, és múlattató történetek, Római mesék, jelennek-meg minden második hónapban; a' Kötet, nyóltzad rétben van, szép nyomtató papíroson, szép betükkel, rózsá szín boríték alatt, gyönyörü rézre metszett képekkel, 12. 's 15. árkusnyi nagyságban. Minthogy pedig annak a' tisztelt szép Nemnek vagyon szenteltetve, melly a' még olly igen tsekély faradságot is figyelmetességére méltóztatja, annyival határozatlanabb bizodalommal tartok számot az ezen munkára való előre fizetés' segedelmére. Az elöre fizetés minden Köttere [!] 30 kr."10

7 SzaJBÉly 2001, i. m. 168.

${ }^{8}$ Escarpit, Robert, Irodalomszociológia $=$ Uö, Irodalomszociológia, A könyv forradalma, ford. Vigh Árpád, Bp., Gondolat, 1973, 57.

9 Vö. FüLÖP 2010, i. m. 70.

10 A jelentés a Rózsa Szín Gyüjtemény egyes köteteinek elején szerepel. Hírlapban: Magyar Merkurius, 1798. máj. 11., 561-562. Landerer Ferenc előfizetési felhívása kísértetiesen emlékeztet az Uránia néhány esztendővel korábbi, A’ Magyar Asszonyi Nemhez címü felhívására. Csaknem megegyező kinyilatkoztatásaik hasonlóságából arra következtethetünk, hogy Landerer Ferenc alighanem a már létező, s az Uránia szerkesztői által kipróbált gyakorlat átvételében látta a sorozat sikeres múködtetésének zálogát: „Majd nem tellyes bizonyossággal lehet tehát reményleni, hogy 
Megszólítása a női olvasóközönség jobbára románokat preferáló olvasásgyakorlatának korabeli, szintén ideologikus mintázatokon nyugvó szólamaira vezethető vissza, ${ }^{11}$ lévén, hogy elvi síkon értelmezi a „szép nem” kívánalmait és elvárásait. Elgondolásában evidenciaként jelenik meg, hogy az alapvetően erkölcsi, ugyanakkor mulattató történetek utat találnak olvasóikhoz. Ideologikus közönségképzetének megfogalmazása mellett azonban kiemelkedő szerepbe kerül a gazdasági szemlélet is: a kötetméretre, a papírminőségre, a tipográfiára, a külalakra és az előfizetés részleteire vonatkozó megjegyzések reprezentatív jelei, hogy Landerer Ferenc alapvetően üzleti vállalkozásként tekint románsorozatára. ${ }^{12}$ Megindításával Landerer Ferenc bevezet egy olyan új, markánsan anyagi érdekeltségek erőterében formálódó terméktípust, amely viszonyítási pontként szerepelhetett a későbbi románsorozatok számára, az olvasóközönség megszólításának, s a kiadandó kötetek kiválasztásának gyakorlatában egyaránt. Figyelem ezúttal nemcsak az egyes, önálló szövegekre helyeződött, hanem az azokat egységbe rendező sorozatra is, amely az értékesítési szempontok mellett meghatározta a lefordítandó müvek kiválasztását is, hiszen a sorozat feltételezett olvasóközönségét csak az igényeknek és az olvasói elvárásoknak megfelelö szövegek kiadásával lehetett megtartani. Ugyanis „,egy kiadó sem engedhette meg magának, hogy egy munkát olyan példányszámban állítson elö, amelyet a piac nem tudott belátható időn belül felvenni - ez ugyanis az eladatlan példányok számának növekedésével - vagy legalábbis a lassú értékesítés miatt jelentős ösz-

valamint nem lész foganatlan, úgy nem is lész kedvetlen Hazánknak szép Neme előtt egy olly Munka - a' melly különössen az Asszonyi Nemet illető esméreteket hozzon forgásba; kedveltető móddal hasznos Tanításokat adjon; mulattasson is, oktasson is, készíttsen jó, 's gondolkodó Anyákat [...] Hogyha bizodalmunknak az elö-segéllők' száma meg-felel, igyekezni fogunk a' Munkának külső Ékességét is meg-adni. Minden kötet ró'sa szin borítékban fog az elö-fizetőknek kezéhez kủldetni. A’ papiros tsínos, és szép; a' betủk újjak és tiszták. Minden kötethez járúlnak a' foglalattal meg-eggyező réz-mettzések, mint: nevezetes Személlyek' ábrázati, viseletek', eszközök', épűletek', tájékok' 's effélék' rajzolati. Egy kötet' nagysága fog állani 20-25 árkusból. Az elő-fizetés fél esztendőnként fog be-szedetni három forintjával. És így egy egész esztendő' folytáért, az az négy köttetért 6 for." Magyar Hirmondó, 1794. február 28., 301-304. (Az idézet innen: 302-303.)

11 BÜKyné Horváth Mária, A Landerer-család és nyomdászati vállalkozásai = Magyar Könyvszemle, 1966/1, 20; vö. Pogány György, Nézetek a nöi olvasásról Magyarországon a felvilágosodás első szakaszában = Könyvtári Figyelö, 2008/3, 450-462; KéRI Katalin, „Nők csak mértékkel olvassanak...", Adalékok a hazai nöi olvasóközönség 18-19. századi formálódásának történetéhez $=$ Pedagógia - Oktatás - Könyvtár, Ünnepi tanulmányok F. Dárdai Ágnes tiszteletére, szerk. Csóka-Jaksa Helga, Schmelczer-Pohánka Éva, Szeberényi Gábor, Pécs, Pécsi Tudományegyetem Egyetemi Könyvtár és Tudásközpont, 2014, 319-341; PAPP Júlia, ,,Ti vagytok a polgári Erény 's Nemzetiség védangyali...", Női olvasás a felvilágosodás és a kora reformkor időszakában = A zsoltártól a rózsaszín regényig, Fejezetek a magyar női művelődés történetéből, szerk. Papp Júlia, Bp., Petőfi Irodalom Múzeum, 2014, 141-161.

12 Vö. Löwenthal, Leo, Irodalom és társadalom, ford. Kárpáti Zoltán, Bp., Gondolat Kiadó, 1973, 106. 
szegü tôke lekötésével járt volna." ${ }^{13}$ Ez egyrészt biztosította a kialakítani kívánt közönség felvevőképességének szinten tartását, igazodva ahhoz az implikált olvasóképzethez, melynek elvárási horizontját a sorozat megcélozta, másrészt viszont ignorálta a magasabb esztétikai befogadóképességet megkívánó szövegek sorozatbeli jelenlétét. A tömegkultúra irányába elmozduló folyamat, eltérő gyorsasággal és intenzitással, minden európai országban végbement, $\mathrm{s}$ ennek részint okaként, részint következményeként kialakult a művészek (szerzők) azon rétege, ,amely a széles olvasóközönség szükségleteinek a kielégítésére törekedett. És ebben az évszázadban lángoltak fel először a tömegkultúra körüli viták is."14 A változásokat figyelemmel kísérő merészebb könyvkiadói stratégiák igyekeztek egy populáris(abb) könyvpiacot megteremteni, elsősorban a népszerü olvasmányok iránt érdeklődő közönség megnyeréséhez kapcsolva a vállalkozás sikerességét. Ez többféle feltételhez kötődött: „az előállítási költségeket, ennélfogva az eladási árat leszorító kiadói taktikához; a termékek városi vagy falusi házalás útján való terjesztéséhez; s olyan szövegek vagy mủfajok kiválasztásához, amelyek a lehető legnagyobb számú olvasót voltak képesek megragadni." ${ }^{15}$ Mindezt megelő(lege)zi a folyamathoz szervesen hozzátartozó elóállítási procedúra, ${ }^{16}$ ugyanis az előállítást megelőző munkálatnak kezdettől fogva számolnia kell a megcélozni kívánt olvasóközönség összetételével. „Sok minden függ attól, hogy néhány száz könyvbarát számára készülő luxuskiadásról van-e szó, vagy egy nagyközönségnek szánt olcsó kiadásról: a papír, a formátum, a nyomdai eljárás (betütípusok kiválasztása, szedéstükör stb.), az illusztráció, a kötés, különösen pedig a példányszám." ${ }^{17} \mathrm{~A}$ fentebb említettekre vonatkozó mérlegelés pedig már a kiválasztás periódusában releváns feltétel, hiszen a majdani célközönség érdeklődéséhez igazodó szempontok szerint történik. ${ }^{18}$

Landerer Mihály pozsonyi románsorozata, a Téli és Nyári Könyvtár másféle szempontrendszert érvényesítve önértelmezésében és közönségképzetében a tudós hazafiság közösségének ideologikus diskurzusához kapcsolódik, amikor a sorozat egyes köteteit a „tudós Olvasóimnak”, a „drága Magyar tudós Publikumnak”, a „leg-főbb tiszteletre méltó Hazabéli Publikumnak”, a „Tudós Magyar Hazámnak” vagy a „Nemes és tudós Publikumnak” ajánlja. Debreczeni Attila szerint a „tudós hazafiság eszméje nagyon alkalmas volt a közösségképző szerep betöltésére, hiszen olyan általános, ideologikus karakterü volt (a tudományok

13 Febvre, Lucien, Martin, Henri-Jean, A könyv születése, A nyomtatott könyv és története a 15-18. században, ford. Csernus Anikó, Szász Géza, Bp., Osiris Kiadó, 2005 (Osiris tankönyvek), 217-218.

14 Löwenthal 1973, i. m. 16-17.

15 CHARTIER, Roger, „Népi” olvasók, „,népszerü” olvasmányok a reneszánsztól a klasszicizmusig = Az olvasás kultúrtörténete a nyugati világban, szerk. Guglielmo Cavallo, Roger Chartier, ford. Sajó Tamás, Bp., Balassi Kiadó, 2000, 308.

16 Escarpit 1973, i. m. 57.

$17 U$ U.

$18 U$ U. 
terjesztése, a nemzet felemelése, a magyar nyelv megóvása stb.), amely a legszélesebb körben lehetővé tette az azonosulást." 19 A megszólítani kívánt közönség képzete meghatározó a sorozat önértelmezésére nézvést, ${ }^{20}$ ezért Landerer Mihály a tudós hazafiakat, többnyire a Téli és Nyári Könyvtár köteteinek paratextusaiban megszólító gyakorlata „azt a feltételezett olvasót jeleníti meg, aki nyilvánvalóan egy véleményen van a szerzővel [esetünkben a kiadóval - B. N.] az adott mü (és általában bármely mủ) funkcióját tekintve, azaz a magyar nyelv és ezáltal a haza szolgálatára rendeli a literátori tevékenységet." ${ }^{21}$ Pusztán ideológiai síkon azonban nem lehetséges sikeres vállalkozást építeni, ezzel nyilvánvalóan Landerer Mihály is tisztában volt, amikor az olvasóközönség megszólítása után ismerteti a következő kötet megjelenésének időpontját, valamint közli a már kapható kötetek legfontosabb, az értékesítés szempontjából lényeges paramétereit. Az Eggenberger József kiadásában induló Eredeti Magyar Románok Landerer Mihály gyakorlatához hasonlóan a tudós hazafiság közösségén belül képzeli el a sorozatban megjelentetni kívánt románok tematikai pozicionálásának kereteit, kiemelt fontosságot tulajdonítva az eredeti müveknek. Az első kötetet jegyző Ilosvay Sámuel a következőképpen közvetíti Eggenberger koncepcióját „Elöre bocsátott Beszédében”: „A' mi Nemzetünk, Karikliát, Kártigámot, Kassandrát régen gyönyörködve forgatja; nem is tagadhatni, hogy ezen munkák' olvasása olly tetemes hasznot szerzett légyen az olvasóknál: hogy az Iróknak érdemeit mindenkor tisztelettel említhetjük. De vallyon, nem volna é ezen Munkák' foganatossága nagyobb, ha a' Hazai Történetekből választott Tárgyakat, a' feltüzesültt képzelődés, úgy festené hazafiui érzékenységgel az olvasó előtt, hogy gyönyörködtetése közben Nemzeti érzést is gerjesztene? - Én úgy reménylem, hogy meg nem tsal hizelkedő magam szeretete, ha a' Hazai Irókra azt a' kötelességet hárítom, hogy kedveskedő Munkáikkal egyszersmint a' hazafiui érzést is tartoznak nevelni." ${ }^{22}$ Mindezek megerősítéseként a felhívás egy felszólítást is megfogalmaz, amelyben hangsúlyos logikai pozícióba kerül a hasonló típusú müvek közzétételének szorgalmazása: „Te kegyes Olvasó! [...] ha egy kis időt az olvasásban kellemetesen töltöttél, bíztasd Hazánk Tudós fiait azon felséges igyekezetre, hogy gyönyörködtető munkáikkal a' Hazafiuságot is mélyebben gyökeresítsék."23

Kis János Flóra címủ sorozatának informális kritériumok alapján elvonatkoztatott közönségképzete csupán részlegesen érintkezik „elödei” ideologikus elképzeléseivel. „Barátomhoz” megszólítással kezdődő előszavában konkrétan

19 DeBRECZENI Attila, Tudós hazafiak és érzékeny emberek, Integráció és elkülönülés a XVIII. század végének magyar irodalmában, Bp., Universitas, 2009, 58.

${ }^{20}$ LABÁDI Gergely, Könyvek távolról: A magyar regény 1807-ben= Irodalomtörténet, 2014/3, 325. [A továbbiakban: LABÁDI 2014a.]

${ }^{21}$ Debreczent 2009, i. m. 54.

22 [Ilosvay Sámuel], Palugyay története, melly az iffjú Palugyay Andrásnak Bubek Kriskával való hív szerelmét foglalja magában, Pesten, Eggenberger Jósef Könyvárosnál, 1807, 4.

23 [Ilosvay] 1807, i. m. 6. 
a megszemélyesített közönséghez fordul, az elvont diskurzusokhoz kapcsolódó kliséket egy bensőségesebb, a magánbeszélgetés, vagy a levelezés formuláit idéző megszólalásmód keretében alkalmazva: „Mi meg vagyunk győzettetve, 's tapasztalásunkból is tudjuk, hogy az ollyan románok, mesék, versek és egyébb múlattató darabok, mellyeket a' jó izlés az okosság' vezérlése alatt dictál [...] nem tsak meg nem vesztegetik a' lelket 's lassú mérget nem hintenek a' jó erköltsök' gyökerére, [...] hanem inkább az értelemnek a' gondolkodást kellemetesebbé tészik, a' szívbe a' leg szebb indulatok' magvát hintik, 's a' képzelődést szép nemes és felséges képekkel töltik meg. Mi mind ezeken kívül még arról is meg vagyunk győzettetve, hogy az igaz Böltseink által irattatott múlattató munkák a' léleknek ki pallérozására nem tsak leg kellemetesebb és leg hathatósabb eszközök, hanem illendő mértékben el múlhatatlanúl szükségesek is." ${ }^{24}$ Erre nézve a közzétenni kívánt sorozat csekély elömenetel, mégis részt vállal e folyamatban: „Ime’ én ismét egy lépést teszek, ismét egy gyüjteménnyel állok elö. Tsekélység ez, jól tudom; még is néked ajánlom, azért hogy a' Te gyönyörủ elmédet ennél sokkal szebbnek, jobbnak 's tökélletesebbnek írására ösztönözzem. Vedd jó néven barátodtól 's hitesd el magaddal, hogy valamig a' szentséget, jóságot, igazságot 's szépséget testvéreknek tartom, 's valamig szívemnek ezen bálványait minden erőmből tisztelem és szeretem, mind addig foglak tisztelni, és szeretni Tégedet is." ${ }^{25}$

Csakhogy Kis János kultúraközvetítő és műveltségpártoló intenciói hátterében feltünik az anyagi érdekeltségü motiváció is, a pénzkereseti lehetőség. Kazinczy Ferenchez írott levelében teszi szóvá a Flóra köteteit illető bizonytalanságát, amely összefüggésre utal a fentebb idézett, föként ideológiai mintázatokon nyugvó előszó határozottságot sugalmazó kitételei, s Kis János valós szándéka között: „Már most ollyan gondolattal vagyok, hogy a’ magam költségén próbáljak valamit nyomtattatni. Mit tanátsolsz erre nézve Te, a' kinek olly sok tapasztalásaid vagynak, 's a' ki a' Hazának azt a' részét lakod és nézed visgáló szemekkel, mellyben a' Magyar könyvek' olvasása legnagyobb divatjában van? Ebben mellesleg az is lenne tzélom, hogy munkáimból valami kis jövedelmet vehetnék; mert akarmiképp visgálom sorsomat, úgy találom, hogy erre is igen szükséges tekéntenem. Mit gondolsz, boldogúlhatok-e némelly popularis és gyönyörködtetésre tzélozó munkákkal ezen szándékomban?"26 Labádi Gergely szerint Kis János a piaci logika szerint müködő kiadói igényekhez és a feltételezett közönségízlés kiszolgálásához füződő viszonya alapvetően kétféle stratégia erőterében formálódik: „egyrészt nem tekinti az ezeket kielégítő kiadványokat komolyan számba vehető munkának, és eltávolító gesztusokkal kommentálja őket, másrészt viszont

${ }^{24}$ KIs János, ** Barátomhoz = Flóra, vagy szívreható apró románok, erköltsi mesék, versek, és egyéb hasznosan gyönyörködtetö Darabok, A' Szép Nemnek, és a' Szép Nem’ Barátjainak. Zaid' Kiadója által, I, Pesten, N. Kiss István Könyv árosnál, 1806, 4-6.

${ }^{25}$ KIs 1806, i. m. 6-7; vö. KulcSÁR 1943, i. m. 65-66.

${ }^{26}$ Kis János levele Kazinczy Ferencnek, 1805. ápr. 6., KAzINCZY Ferenc Levelezése, 18031805, III, kiad. Váczy János, Bp., MTA, 1892, 313. 
a felvilágosodás kori magyar irodalom kedvelt közhelyéhez nyúlva az irodalom előkészítő szerepével érvel mellettük." ${ }^{27} \mathrm{E}$ két stratégia azonban rendre kiegészül két másik, főként a levelezésben mintázódó stratégiával, a személyes szempontként értelmezhető pénzkereseti tevékenységgel, valamint a népszerü narratív szövegek kapcsán felvetődő nyelvi kérdések előtérbe helyezésével. ${ }^{28}$

Hartleben Konrád Adolf vállalkozása már címében is vállaltan hirdeti, hogy szórakoztató olvasmányok közzétételét tüzi ki célul, a közhelyszerü utile et dulce horatiusi gyökerü érvkészletét használva fel Mulatságos Könyvtár című sorozatának legitimálásához: „Hasznosok, sőtt szükségesek a’ mulatságos el-beszéllések, történetek. Hasznosok; mert ha ki szerentsés etsettel le irja az emberi szív képét, a' fontos, ritka, 's különös esetekben az érzeménynek egy hiv tükrét tárja fel az Emberiség elibe. [...] Szükségesek; mert a' takarékos Házi-Aszszony; ha el járt dólgaiban, a' foglalatos Férjfi, ha tsüggesztő munkáji után enyhülni kíván, ha az Ifiú, a' Leányzó az élet veszedelmibe hanyat-homlok rohanni [...] nem akar, kedvesen venné, ha egy könyvben mulatságot, 's Kalauzt találhatna." 29 E kitételekre és evidenciákra alapozva határozza magát arra, hogy románsorozat közzétételével csatlakozzon az olvasóközönség „gyönyörködtető pallérozásához”: „Én el tökéllém magamban, hogy ezen tzélban eszközlő lenni törekszem: azért is egy Román gyüjteményt adok ki illy szim alatt: MULATSÁGOS KÖNYV-TÁR A' PALLÉROZOTT OLVASÓKNAK. Ezen gyüjtemény olly Iróknak munkájok, kik az írásban nem most törik a' jeget, 's az e' félékben a' leg-jelesebbek közzé tartoznak. Benne a' tárgyaknak különösségök, az irás-módnak lelkesítő kellemei [...] mindenütt tsalhatatlan gyönyörüséggel tőltik el a' Pallérozott Olvasót, 's haszonnal vegyítik a' mulatságot." 30

Hartleben, Landererhez hasonlóan azonban nem feledkezik meg arról, hogy az ideologikus szólamokat a kötetek értékesítésének sikeressé tételéhez nélkülözhetetlen, a piaci logika szerint müködő pragmatikus információkkal egészítse ki: hirdetését természetesen e logikának megfelelően a megjelentetni kívánt kötetek címének, tipográfiájának, külalakjának ismertetésével, s az előfizetési felhívás részletezésével zárja, bízván az ún. „pallérozott olvasók” érdeklődésében. Magabiztosságát szemlélteti, hogy bátran az előfizetők tudomására hozza, a pestiek nem prenumerálhatnak a sorozatra, hanem egyenként, személyesen vehetik meg köteteit. Vállalkozása nem előzmények nélkül való, ti. néhány esztendővel korábban Hartleben kiadásában valósult meg az osztrák Eipeldauer Briefe hosszú éveken át működő sorozatának hazai átültetése, a Gaál György által készített $A$ ’tudós Palótz, avagy Furkáts Tamásnak Mónosbélbe lakó sógor-urához írt levelei címü többkötetes elbeszélésfüzér. Joseph Richter szerzeményének rendkívüli népsze-

${ }^{27}$ LabÁdi Gergely, A'Magyar Páméla és forrása = KIs János, A'Magyar Páméla, kiad. Labádi Gergely, Bp., reciti, 2014 (ReTextum, 1), 21.

${ }^{28}$ Uo.

${ }^{29}$ Holosovszky Imre, Lelemények, Pesten, Hartleben Konrád Adolf könyvárosnál a’ Vátzi Utszában, 1808, [oldalszám nélkül].

${ }^{30}$ Uo. [Kiemelés az eredetiben - B. N.] Vö. KulcsáR 1943, i. m. 62. 
rüsége Hartleben érdeklődését is felkelthette, aki Gaál Györgyöt bízza meg egy hasonló alkotás elkészítésével. Richter alapötletének magyar átdolgozása meg is jelenik hat kötetben, hazai jelentőségéről viszont aligha beszélhetünk. ${ }^{31}$ Mulatságos Könyvtár címen indított sorozatának fényében azonban úgy tünik, a korábbi sikertelenség sem tántoríthatta el Hartlebent hasonló típusú beruházásoktól. Szerteágazó, sok esetben következetlen könyvkiadói tevékenységének anyagi érdekeltségét jól szemlélteti Horvát István naplórészlete, amelyben egyértelmüen utal a kiadó gyakran kudarcokkal végződő vállalkozásainak szervezetlenségére: „Hartleben Konrád Adolf, könyv árosságának jövedelmeit egyszerre ezerekkel akarván szaporítani, minden módokat (planum) ki találni iparkodott elöször, de látván, hogy nintsen ugrás a' természetben, gyalázatosan meg tsükkent. Által vette elejénten mindjárt a' Schediustól íratott Zeitschrift kiadatását; készítetett Lübek által Patriotische Vochenblatot; íratott Tudos Palótzot; el kezdette Versegivel a' jelesebb Theátromi Daraboknak fordíttatásokat, Lapithie Frantzia könyvnek fordítatását, 's a' t; által akarta venni, nyomtatás kedvéért ugyan azon Verseginek Grammatikáját, s' a' t. - Mi lett mindenekből? A' Zeitschrift, Vochenblat egy esztendő múlva nála el haltak; A' tudos Palótz meg szünt, és nyomtatványai Kisnek oltsó áron által engedtettek; Kolomposi első kötetkéjét Eggenbergernek Versegi több írásaival együtt (Verseginek minden tudomása nélkủl) el adta; a’ La Pithie frantzia költeménynek fordíttatását félbe hagyatta; az Edvárd komédiának (melyly a' Theátromi Gyüjteményben első részt foglalt, de ezen Tzimjét Eggenbergertől, kinek már nem egy volt plánuma, el vesztette, és tsupán együgyü homlok írást nyert) végig esendő kijöttét a' nyomtatás alatt Eggenbergerre tuszkúlta; Kolomposi második kötetkéjének kéziratát, Versegi Grammatikájának némelyly tisztára le írt részét, Kolomposi első kötetjének nyomtatványait, szint úgy tsekély füzetésért Eggenbergerre tólta." ${ }^{32}$ Mint ismeretes, a Mulatságos Könyvtár sem müködött tovább egyetlen esztendőnél. Nem véletlen, hogy a magyar nyelvü könyvek árusításának sikertelensége folytán Hartleben fokozatosan áttér a pest-budai német polgárok igényeit megcélzó német nyelvű kiadványok terjesztésére. A későbbiekben teljes mértékben átszervezi kiadói vállalkozását, kizárólag német nyelvü könyvkiadásra összpontosítva. ${ }^{33}$

Látható, hogy a románsorozatok látens piaci versenyében a pozicionálás és a közönségképzet diszkurzív határainak lefektetése az olvasóközönség (nem feltétlenül sikerrel kecsegtetö) megnyerésének első lépéseit jelentik. Szempontunkból relevánsabb, hogy az ideologikus, programos elgondolások hátterében kibontakozik a pragmatikus, utóbb markánssá váló gazdasági szemlélet is, amely egyértelmüen a románsorozatokat gazdasági vállalkozásokként elképzelő kiadói megfontolásokat szemlélteti. A korabeli hírlapok felületén publikált tudósítások-

31 Vö. SZILÁGyi, VAderna 2010, i. m. 401-404.

${ }^{32}$ Mindennapi, Horvát István pest-budai naplója 1805-1809, szerk. Szauder Józsefné, Temesi Alfréd, Bp., Tankönyvkiadó, 1967, 68.

33 GÁRdonyi Albert, Régi pesti könyvkereskedők, Bp., A Magyar Nemzeti Múzeum Országos Széchényi Könyvtára, 1930, 81-82. 
ban, jelentésekben és hirdetésekben e pragmatikus elv dinamikus előtérbe-kerülése jellemző.

\section{„Literátori” és/vagy , Tudománybéli” Tudósitások (pragmatikum)}

Említett kiadóink közül Landerer Mihály az egyetlen, akinek hirdetői gyakorlatában kontinuitás fedezhető fel a 18. század utolsó, és a 19. század első évtizede között. Miután 1795-ben családi örökségként átveszi a kiterjedt fiókhálózattal müködő Landerer-nyomda irányítását, állandó hírlapi jelenlétével igyekszik biztosítani a kiadóhálózat termékeinek széles körü megismertetését. ${ }^{34} \mathrm{~S}$ e jelenlét nem csupán a kiadott, vagy kiadni kívánt kötetek promócióját érinti, de kitekintést enged Landerer széles vállalkozói tevékenységének más ágazataira is, legyen szó a lublói savanyúvíz, ${ }^{35}$ vagy Török Lajos gyógyító hatású készítményének árusításáról. ${ }^{36}$ Sokatmondó, hogy Peretsényi Nagy László magasztaló hangvételü sorokkal köszönti a nyomdász-könyvkiadót: „Hálá légyen a’ Magyarok’ irgalmas Istenének! Már mi fölöttünk is Füskúti Landerer Mihály Urnak személyeben kegyessebb tsillagzatok kezdenek minden felül ragyogni; tudniillik: ez a' Nemes Hazafi a' leg-távolabb-lévő Magyarokat-is attyafiainak ésmérvén, hogy módot adna mindnyájunknak a' Szép tudományoknak meg-ismérésére, kedvellésére, és gyakorlására, naponként szaporittya a' Magyar könyveket, és a' mint sok izbéli tudositásai nyilvánositják, tellyes erővel igyekezik a’ Magyar Litteráturát nem tsak előbb-mozditani, hanem ki-is terjeszteni. ${ }^{37}$ Landerer kiadói érdemeit Arkhimédész, Kopernikusz, Newton érdemeihez méri, sőt, ezekénél jelentősebbeknek ítéli, hiszen az említett személyek csupán a múveltebb, tanult elméket kecsegtették tudományos tevékenységükkel, velük szemben Landerer munkái „a kacagányos, és gubás Magyarainkat is a háládatosságra kötelezik”. ${ }^{38}$ Peretsényi mondatai nyilvánvalóan túlzásokkal terheltek, a magasztaló metaforika hátterében azonban lényeges, Landerer következetes kiadói, s hirdetői gyakorlatával kapcsolatos meglátások fedezhetők fel. Látható, hogyan kapcsolódik Peretsényi ahhoz a retorikai utalásrendszerhez, amely a magyar nyelvü müveltség pártolá-

${ }^{34}$ Valószínüsíthető, hogy a kiadói tevékenység mellett e termékek hirdetésének feladata is hagyatékként került Landerer örökébe, az idősebb Landerer kifogásolható hirdetői gyakorlatát ugyanis már Kazinczy szóvá teszi Ráday Gedeonhoz írott levelében: „Suffena omnia colligam venena. Ezt Landerer meg-érdemli, mert minden választás nélkül ád-ki mindent, 's a' Haza-szeretetivel fedezgeti a' pénz után való ásítozását." Kazinczy Ferenc levele Ráday I. Gedeonnak, 1786. okt. 19., KAZINCZy Ferenc Levelezése, 1927 óta elökerült, és kötetbe nem foglalt levelek gyüjteménye, XXIII, kiad. Berlász Jenő, Busa Margit, Cs. Gárdonyi Klára, Fülöp Géza, Bp., Akadémiai, 1960, 16. [Kiemelés tőlem $-\mathrm{B}$. N.]

${ }^{35}$ Magyar Kurír, 1801. júl. 3., 15-16.

${ }^{36}$ Magyar Hirmondó, 1799. febr. 8., 178.

${ }^{37}$ Magyar Kurir, 1798. szept. 7., 315-316. [Kiemelés az eredetiben - B. N.]

38 Uo. Dicsérő sorait egy héttel később a Magyar Hírmondóban is közzéteszi: Magyar Hírmondó, 1798. szept. 14., 350-352. 
sának eszményén keresztül a tudós hazafiak ideologikus közösségéhez rendeli Landerert, s amely meghatározó jelentőséget kap a Téli és Nyári Könyvtár pozicionálásakor.

Sorozatokról lévén szó, a folytonos müködtetés anyagi erőforrások konstans mozgósítását előfeltételezte, magyarán az egyes kötetek értékesítése alapvető feladatként jelentkezett valamennyi kiadó számára. „A mű egyéb ismérveit tekintve, a feltételezett közönségnek nem csupán a nagyságát kell számításba venni, hanem természetét, funkcionális igényeit, legfőképpen pedig lélektanát is." 39 A könyvtermék e kívánalmakhoz igazodó profanizálódásának első jeleit a kiadók által közzétett rövid, mindössze néhány oldalas könyvjegyzékek, a vásárlók tájékoztatására szánt katalógusok jelzik. ${ }^{40}$ A 19 . század első évtizedeire kibontakozó tudatos közönségszervezés, olvasóvá-nevelés módozatainak a század vége óta formálódó hírlapirodalom biztosít adekvát megnyilvánulási felületet. A hirdetés közvetítő, propagáló szerepére már korán felfigyelnek a hírlapszerkesztők, ${ }^{41}$ kettős funkciót rendelve a hirdetés megjelentetéséhez: elsősorban a literatúra széles körben való terjeszthetőségének letéteményesét, a kurrens népszerüségnek örvendő románt közvetíti az olvasóközönség felé, másodsorban hangsúlyozza a periodikáknak e folyamatban betöltött, egyre inkább megkerülhetetlennek bizonyuló szerepét.

Legyen szó a Magyar Kurír, a Magyar Hirmondó, a Magyar Merkurius vagy a Hazai Tudósitások hirdetéseiröl, valamennyi esetben a kötet, vagy kötetek ismertetése kerül lényegi pozícióba, a feltételezett olvasóközönséggel folytatott ideologikus beszédmód látványos háttérbe-szorulásával. Landerer Mihály rendszeresen tudósít a pesti József-napi, ${ }^{42}$ Medárd-napi ${ }^{43}$ János-napi, ${ }^{44}$ Lipót-napi ${ }^{45}$

39 Escarpit 1973, i. m. 58.

40 SzALisZnYó Lilla, „Imhol a' Jelentés”, A magyar irodalom propagálása a 19. század első évtizedeiben = Piacok a társadalomban és a történelemben, szerk. Halmos Károly, Kiss Zsuzsanna, Klement Judit, Bp., Hajnal István Kör - Társadalomtörténeti Egyesület, 2014, 373; vö. KulcsÁR 1943, i. m. 15-16.

${ }^{41}$ Fontossága már a Mindenes Gyüjteményben megfogalmazódik, amely a hirdetések kapcsolatképző funkciójára irányítja a figyelmet: „A’ két Hazában lévő Könyv-nyomtató Urak, ha idején túdósítanak minket az eránt, minémű új Könyveket kívánnak a’ Pesti Vásárokra le-vinni vagy kủldeni, azokat is hírül adjuk Gyülyteményünkben, hogy tudja mind a’ két Haza, minémú új munkák jőnek világosságra, 's hol és kinél, 's mitsoda árron szerezhesse-meg akármellyikét is, - az a' ki ólvasni szeret. Sőt a' melly Túdós Hazafijak akármelly túdós munkákon dólgoznak, azt is ha meg-tudhatjuk, készek lészünk előre meg-jelenteni, hogy ne talám magók is ugyan azon munkákban fáradozzanak." Mindenes Gyüjtemény, 1789/1. negyed, 13. levél, 208.

${ }^{42}$ Magyar Hírmondó, 1797. márc. 3., 277-280; Magyar Hírmondó, 1798. márc. 6., 320; Magyar Merkurius, 1795. márc. 6., 283-288; Magyar Merkurius, 1796. febr. 26., 242-244; Magyar Merkurius, 1798. márc. 2., 269-270.

${ }^{43}$ Magyar Merkurius, 1795. máj. 15., 547-548; Magyar Merkurius, 1796. ápr. 26., 498-500; Magyar Kurír, 1803. máj. 3., 559-560; Magyar Kurír, 1803. máj. 10., 590-592.

${ }_{44}$ Magyar Kurír, 1803. aug. 16., 221-224; Magyar Kurír, 1803. aug. 19., 237-240.

${ }^{45}$ Magyar Hírmondó, 1798. nov. 6., 590-592; Magyar Kurir, 1798. okt. 30., 553-554; Ma- 
vásárokon megvásárolható köteteiről, részletes, az egyes kötetek címleírásai mellett a kiadványok méretét, árát, s egyéb paramétereit ismertető könyvlistákon keresztül. Rendszerszerüvé váló hírlapi jelenlétét az említett orgánumok felületén nagy számban közzétett jelentés, tudósítás vagy hirdetés szemlélteti. Következetes hirdetői gyakorlatával keveseknek sikerül lépést tartani, Wéber Simon Péter, Kiss István, Hartleben Konrád Adolf hasonló tudatossággal, de kevésbé rendszeresen, Eggenberger József vagy Trattner Mátyás inkább alkalomszerüen szerepel a hírlapi nyilvánosságban. Sokatmondó, s szempontunkból alighanem példaértékü Hartleben a Magyar Kurír 1808. november 18-i számában közzétett jelentése (Hartleben Konrád Adolf Könyváros' boltjában a' Két Választó fejedelmekkel által ellenben lehet találni még ezen új Könyveket-is), melyben a kilenc tételes könyvlistából nyolc tétel a saját kiadásában megjelenő románra vonatkozik. ${ }^{46}$ Szó sem esik „,szép nemről”, „tudós publikumról”, „hasznosságról”, vagy „pallérozásról”, a jelentés egyértelmüen értékesítendő termékként tekint a felsorolt kötetekre, s így azok legrelevánsabb komponensét, az árat igyekszik minden esetben feltüntetni. A korszakban közzétett hirdetések, jelentések és tudósítások szerteágazó konglomerátumából e fenti közlemény tekinthető a korszak egyetlen, szinte csak románokra összpontosító hirdetésének. Tartalmi összetételét, s publikálásának körülményeit tekintve nem véletlen, hogy éppen az 1807 és 1808 közötti kiemelkedő időszakban kerül a nyilvánosság elé. E két esztendő, a sorozatokban kiadott kötetek és az őket tematizáló hírlapközlemények számát tekintve ugyanis egyértelmü kulminációs pontként értelmezhető, ti. az említett románsorozatok közül egy időben müködik a Téli és Nyári Könyvtár, a Flóra, az Eredeti Magyar Románok és a Mulatságos Könyvtár. ${ }^{47}$

Arnyalatnyi terminológiai különbségtétel ugyan mutatkozik az egyes hirdetéstípusok használatában, tartalmi differenciálás azonban kevés esetben érzékelhető. A „Tudósítás”, „Jelentés”, „Híradás” lényegében egy jelentésmezőbe tartozó „steril” fogalmak, végső arculatukat a kiadói „felhasználás” során, a periodikák felületén nyerik el. Pontos elkülönítésük ezért ütközhet problémába. ${ }^{48}$ Mindezeken túl a kiadók eltérő formai kritériumok szerint teszik közzé hirdetéseiket: egyesek csak a címek felsorolására szorítkoznak, mások részletesebb könyvészeti adatokkal, (a pragmatikus szemlélet előtérbe-kerülését illusztrálandó) az értékesíteni

gyar Kurir, 1799. okt. 25., 544; Magyar Kurír, 1803. nov. 1., 567-568; Magyar Kurír, 1803. nov. 8., 598-599; Magyar Kurir, 1803. nov. 15., 630-632.

${ }^{46}$ Magyar Kurir, 1808. nov. 18., 654-656.

${ }^{47}$ Beleértve a sorozatoktól függetlenül kiadott köteteket, 1807-1808 között összesen huszonnégy román hagyta el a nyomdaprést (Ajtay Sámuel, Bachich József, Dugonics András, Farkas Ferenc, Fáy András, Gorove László, Holosovszky Imre, Ilosvay Sámuel, Verseghy Ferenc, s mások munkái). Vö. GYörgY Lajos, A magyar regény elözményei, Bp., Magyar Tudományos Akadémia, 1941, 361-385.

${ }^{48}$ Vö. Czuczor Gergely, Fogarasi János, A magyar nyelv szótára, II, III, VI, Pest, Emich Gusztáv-Athenaeum, 1864-1874, 1591, 250, 479. 
kívánt kötet méretével, árával egészítik ki híradásaikat. ${ }^{49}$ Csupán a gyakorlat következetességében észlelhető azonosság, a gyakorlat részleteiben minden kiadó személyes érdekei, s elképzelései szerint járt el. E heterogenitás részben azon problémára is visszavezethető, hogy maguk a lapszerkesztők sem egységes, letisztult koncepció szerint szabályozták a hirdetések közzétételét. Horvát István és Ferenczy János például több esetben éles kritikával illeti, hogy Kultsár differenciálatlanul rendezi el a Hazai Tudósitások reklámfelületén publikált hirdetéseket. Levelezésükben hol szélhámosságát, felelőtlen ígéreteit teszik szóvá, hol a haszontalannak ítélt tudósítások igénytelen kiválasztását és közlését kárhoztatják, gyakran „hulladéknak” ${ }^{50}$ minősítve Kultsár meg nem nevezett forrásait. Kritikus elítélésükben egyikük sem jósol hosszú életet az ,ezermesterségü” ${ }^{51}$ Kultsár lapjának. ${ }^{52}$ Mint utólag kiderült, nem lett igazuk. ${ }^{53}$ Bár a század első évtizedére a hírlapok és folyóiratok felülete viszonylagos „versenyterepet” is szolgáltatott a kiadók számára, a jól kimunkált hirdetéseken alapuló népszerüsítés önmagában még nem bizonyult elegendőnek egy vállalkozás sikeressé tételéhez. Ehhez kézenfekvő példaként említhető az Eredeti Magyar Románok koncepciózus, mégis bevégezetlenül maradt esete.

49 SzALisZnYó 2014, i. m. 375.

50 „Kultsár Úr Toldi lovaként a'szemeteken gyüti öszve Tudósításait”. Horvát István levele Ferenczy Jánosnak, 1806. dec. 1., Horvát István és Ferenczy János levelezése, kiad. Soós István, Bp., A Magyar Tudományos Akadémia Irodalomtudományi Intézete, 1990 (Commercia Litteraria Eruditorum Hungariae, Magyar Tudósok Levelezése, 2), 44. Másutt: „Tek. Kultsár Uron, ne hogy Toldi lovaként $a$ 'szemeteken kénszerittessék Tudositásait keresgélnie, segíteni iparkodtam egy kevesé, mert arról meg vagyok gyözetve, hogy kevés értékü lehet az, a'mit szemeteken találhat. Nem is illendő illyetén ringy rongyokat egy ditső Nemzet elejébe, millyen a' Magyar, föl adni. Nagyot köll gondolni a’ Magyar lélekröl: meg sértetik az, ha gyim gyom partékát küldetnek meg ítélése alá. - Én, hogy tsak ön magam tsekélységéről szoljak példának okáért valamit, soha sem olvashatom szánakodással elegyült ihletődés nélkül az esőről, szélről, 's egyéb hasonlokról szóló hoszszú 's unalmas dadogásokat, mert az üdő viszontagságait minduntalan morogni haszontalanság, 's ollyan dolog, mellyet a' szemét kupatzokon is meg lehet akár melly nézönek látnia. A' Hazai Tudósításoknak Tudósítaniok köll tzéljok szerént: mennyivel válik illyenekből tudósabbá az olvasó? Kevesebbet igérjünk, és többet tegyünk egyfelül: másfelül pedig tehetségeinkhöz mérjük igéretünket." Horvát István levele Ferenczy Jánosnak, 1806. dec. 2., HoRvÁt, FerEnCzy 1990, i. m. 44. [Kiemelések tőlem - B. N.]

51 Ferenczy János levele Horvát Istvánnak, 1807. jún. 27. Horvát, Ferenczy 1990, i. m. 119.

52 Viszonylag korán, a Hazai Tudósitások müködésének második évében megfogalmazódik a szomorú sors (vízionált) előképe: „,ha el gondolom, hogy Kultsár Ujsága vagy haldoklik, vagy közel vagyon a' halálos betegséghöz, a'kor mélyen szomorkodom. Utóbbi leveleiben semmit sem lelek, a’ mi a’ papiros vesztegetést meg érdemlené. Ha így ír sokáig: a’ fél esztendő végével senki sem fogja ujság levelét hozatni, 's nem leszen ismét a' Magyarnak önön Hazájaban ujsága". Horvát István levele Ferenczy Jánosnak, 1807. febr. 10. Horvát, Ferenczy 1990, i. m. 76. Levelezőtársa betegség-metaforikáját alkalmazva Ferenczy is hasonló következtetésre jut: „Kultsár ismét tsügged. Ojan az ö ujsága, mint Révai egészsége, hol eröre kap, hol le rogygyan.” Ferenczy János levele Horvát Istvánnak, [1807. márc. 16. után] HorvÁT, FERENCZY 1990, i. m. 89.

53 Vö. LABÁDI 2014a, i. m. 318. 
Eggenberger 1806 végén jelenti be a Hazai Tudósításokban egy új románsorozat elindításának tervét, melyet a szerkesztő Kultsár lelkes kommentárral közöl: „Pesti Érdemes Könyváros Eggenberger (Baronai) Jósef Úr olly új szándékról tudósítja a' Magyar Hazát, melly neki ditsőségére, minden Hazafinak pedig örömére szolgálhat. Halljuk Jelentésének szavait: »Nagy ditsőségére válik az a' Magyar Nemzetnek, ha az idegen munkák ízetlen fordításaik által nem haggya már tovább magát vezetéken hordoztatni, mint a’ járni tanúló gyermek. Megismérni az elme jussait, és tulajdon lelki erejével a' természetnek és a' régi törtíneteknek mezejeken új pállyafutásra ereszkedni, férfias tselekedet, férfias Nemzetet illet. Kéri azért az alább irtt a' Magyar Nemzetnek Tudós Tagjait, hogy a' Nemzeti Nyelvhez viseltető szereteteket Eredeti Magyar Románok iratásaik által megbizonyítani méltóztassanak. Ez szerezhet nékik állandó ditsőséget, ez nyujthat a’ Nemzetnek igazi hasznos múlatságot.« Ehez képest Eredeti Magyar Románokat szándékozik kiadni, és ugyan esztendőnként két kötetet." ${ }^{54}$ Eggenberger a fordítások deklaratív elvetésével, az eredeti munkák szorgalmazásával tudatosan a Landerer-féle Téli és Nyári Könyvtár ellenében pozicionálja sorozatát. ${ }^{55}$ Vállalkozása végül megreked a kezdeti fázisban, a tervezett esztendőnkénti két kötet helyett mindösszesen Ilosvay Sámuel Palugyay története, valamint Verseghy Báró Külneki Gilméta kisasszony, és Aranypataki György címủ mủve jelenik meg a rövid életü sorozatban. Ráadásul egyik sem tekinthető eredeti alkotásnak, így a megvalósítás végül nem csupán a koncepciónak, de a sorozat címének is ellentmond. Esete, a Rózsa Szin Gyüjtemény, a Téli és Nyári Könyvtár és a Flóra többkötetes sorozatainak árnyékában a termékutánzás gyakorlatának kevesebb erőfeszítéssel járó, de annál kockázatosabb vetületére hívja fel a figyelmünket. Hogy Eggenberger vállalkozásának sikertelenségét milyen mértékben befolyásolhatta a korábban indult sorozatok népszerüségi faktora, nem áll módunkban rekonstruálni, a nyilvánvaló ellentétek jelenléte azonban több esetben érzékelhető. Súlyosbodásukhoz pedig a hírlapszerkesztők, különösen Kultsár feszültségkeltő kommentárjai is hozzájárulhattak. A Flóra harmadik kötetét népszerüsítő jelentésében például egyértelmü malíciózus hangvétellel utal a Rózsa Szin Gyüjtemény és a Téli és Nyári Könyvtár korábbi sorozataira: „Hiero Syrakusai Király’ Történetei. - Pesten N. Kis István Könyvárosnál 1807. 12öd formában. Ezen tiszta Magyarsággal, és elmés el rendeltetéssel készült Költeményes történet árnyékot von mind azokra, mellyek vagy a idötöl, vagy a' boritékról veszik nevezeteket, és ugyan azért a' tárgyakra nézve épen semmi válogatást nem mutatnak. Bár tsak az afféle álomlátások, késértetek, 's több ollyan gyáva lelkeknek táplálásaikra szolgálható munkák ne terhelnék Nemzeti Literaturánkat! - Ezen itt említett Hieró történetei válogatott tárgyakat nyujtanak az olvasásra, és szép rézre metszett képpel vannak felékesítve." ${ }^{56}$ Kultsár kritikus viszonya a korábbi sorozatokhoz egy láthatatlan,

\footnotetext{
${ }^{54}$ Hazai Tudósitások, 1806. nov. 22., 351-352.

${ }^{55}$ LABÁDI 2014a, i. m. 326-327.

${ }^{56}$ Hazai Tudósitások, 1807. aug. 15., 111. [Kiemelés tőlem - B. N.]
} 
a románsorozatok között kitapintható pozíció- és konkurenciaharc kontextusában értelmezhető. ${ }^{57}$

Problémák eszerint már a korai fázisban jelentkeztek. Sőt - amint az Landerer Mihály jelentéséből kitünik -, a kiadókat bizonyos esetekben olyan váratlan szituációk is hátráltatták, amelyek egyrészt felboríthatták az adott kötet esetében végzett anyagi kalkulációkat, másrészt a szervezetlenség gyanúját keltve esetleg rossz fényben tüntethették fel a sorozatot az olvasók előtt. E problémával Landerer Mihály már a Téli és Nyári Könyvtár első kötetének esetében találkozik: „Mivel a’ Nyári, és Téli Könyv-tárnak jelenvaló első Része a’ Betüknek aprósága miatt kevesebb árkusokban, mint eleintén a' Ki-adó sajdíthatta, foglaltatott légyen, és az el-tökéllett szándékának egyedül az a' tzélja, hogy a' tudós Olvasóimnak mennél türhetőbb árron könyvekkel szolgálhasson; erre nézve már hírül adott árrát egy forintról 45 krajtzárokra le-szállította." ${ }^{58}$ Hogy a csorbát kiküszöbölhesse, Landerer a nyomtatói hibát ügyes fogással az olvasóközönség anyagi érdekeire érzékeny kiadói magatartás hangsúlyozásával igyekszik elfedni. A hasonló bonyodalmak elkerülésére azonban nyilvánvalóan minden kiadó figyelmet fordított, hisz a sorozatos tévedések az esetleges előfizetők elvesztésének veszélyével fenyegethettek. A kötetek döntően prenumerációs rendszerben történő értékesítése ugyanis arra figyelmeztet, hogy „,a könyvkiadás indusztrializációjának nem minden eleme volt még teljesen életképes" ${ }^{59}$ Ilyesféle problémával szembesülhetett Hartleben is, amikor a Mulatságos Könyvtár második kötete mégsem az eredeti koncepció szerint jelent meg, Landerer magyarázatával ellentétben azonban Hartleben nem szolgál hasonló mentséggel. Számára fontosabb, hogy még lehet kapni a sorozat első kötetét: „Ezen Könyv-tárból minden Hónapban megjelenik egy Kötet, mindenike egy egy Románt foglal magában, 's magánosan is megvehetni. A' második Kötetben már nem Almarik, hanem egy más Román: Rózika' Titkai, jön ki. Az első Kötetet is, ezen tzím alatt: Lelemények, magánosan meg lehet szerezni." ${ }^{60}$

Az ún. ,indusztrializáció” hosszadalmas, a formálódó olvasóközönség növekedése lassú tendenciát mutat ${ }^{61}$ - e visszatartó körülményekre vonatkozó elégedetlenségeinek a korszak értelmisége gyakorta hangot ad. ${ }^{62}$ Talán érthető, hogy Trattner János Tamás miért érzi parancsolónak, hogy folyóiratközleményben

57 LABÁdi 2014a, i. m. 316-320, 327.

58 Báró de Mánx' lengyel orsz. confed. generálisnak a'tengeren, és szárazon tett Útazásai és tsudálkozásra méltó Történetei, Öszve-szedettek, és magyar nyelven kiadattak hiv unokája által, Pozsonyban és Pesten, Füskuti Landerer Mihálynál, 1805, [200].

59 Szalisznyó 2014, i. m. 369.

${ }^{60}$ Holosovszky Imre, Rózika’ Titkai, Pesten, Hartleben Adolf Könyvárosnál, 1808, [2].

${ }^{61}$ Habermas, Jürgen, A társadalmi nyilvánosság szerkezetváltozása, Vizsgálódások a polgári társadalom egy kategóriájával kapcsolatban, ford. Endreffy Zoltán, Glavina Zsuzsa, Bp., Osiris Kiadó, 1999, 85-101.

${ }^{62}$ Vö. Kornis Gyula, A magyar müvelödés eszményei 1777-1848, Bp., Királyi Magyar Egyetemi Nyomda, I, 1927, 393-395; KulCSÁR 1943, i. m. 80-81. 
értekezzen az elöfizetések szükségességéröl. ${ }^{63}$ Trattner nehezményezi, hogy az olvasóközönség (de főként a könyvvásárlók) csekély száma miatt a könyvkiadás még mindig költséges, s kockázatos vállalkozásnak tekinthető, ebből kifolyólag továbbra is szükség van a hallgatólagos becsületkódexen alapuló előfizetési rendszer fenntartására: „még nállunk kevés a’ könyvevő, de sokkal több az Olvasó; ezen okokra nézve az ollyan Szerző, vagy pedig Kiadó a' ki pénzét kotzkára nem akarja és nem is teheti, szükséges, hogy elöfizetést hirdessen, és ezen úton bégyülendő pénzzel a' nyomtatást vihesse, más részről pedig elérje azon tzélt is, hogy Munkája ez által inkább esméretessé tétessék a' két Hazánkban." ${ }^{64}$ Más kérdés, hogy a prenumeráció hosszú évtizedeken át fenntartott rendszere elsősorban kiadói érdekeltségből müködött, a szerzőkre (s nem mellékesen az előfizető személyekre) kényszerü teherként nehezedett. ${ }^{65}$

Említett példáinkból kitünik, hogy az olvasók megszólítása, az értékesíteni kívánt kötet széles körü megismertetésének feladata milyen hosszú időn keresztül meghatározza a könyvkereskedelem alakulását, a románirodalom térhódítását. Tegyük hozzá, az értékesítési szempontok a kiadási procedúra szerteágazó feltételrendszeréhez, valamint a magyar nyelvü olvasóközönség változó kívánalmaihoz igazodva szüntelen módosulási kényszernek voltak kitéve. Románsorozataink régi századfordulós prosperálása azonban lehetővé teszi azt az óvatos következtetést, hogy e sorozatok, föként a Rózsa Szín Gyüjtemény és a Téli és Nyári Könyvtár egyes kötetei relatív népszerüségnek örvendtek az olvasóközönség előtt, fogyasztói érdeklődés hiányában ugyanis lehetetlen lett volna a sorozatok éveken át történő müködtetése. A románok kiadásának és értékesítésének gyakorlata voltaképp párhuzamosan haladt a magyar nyelvủ nyilvánosság kialakulásával, kapcsolatuk már a kezdetektől megmutatkozik, sporadikusan, nem rendszer-szerúen közölt hirdetéseken keresztül. Minthogy európai viszonylatban a 18. század második felétől fogva a könyvet következetesen kulturális árunak tekintették (fél évszázados fáziskéséssel hasonló átrendeződés kezdeteire figyelhetünk fel a hazai irodalomban is), e gazdasági logika dinamikus előtérbe-kerülésével a „piac az addig domináló árucseréről egyre inkább áttért a kapitalista elvek alapján müködő pénzforgalomra." ${ }^{\prime 66}$ Ahhoz, hogy a piaci logika szerint kibontakozó, új típusú könyvkiadói gyakorlatok eredményesen közvetíthessék termékeiket a vásárlók felé, szükségszerúen számolniuk kellett a nyomtatóprést elhagyó kiadványaik széleskörü megismertetésének feladatával. A kommunika-

${ }^{63}$ TratTNER János Tamás, Az Elöfizetésnek módja, neme, czélja és haszna = Tudományos Gyüjtemény, 1818/10, 109-115.

${ }^{64}$ Uo., 110-111.

${ }^{65}$ Vö. Demmel József, „,...ösmerem ezt az impertinens akasztófára való publicumot”, A prenumeráció forrásértékének vizsgálata Tompa Mihály kapcsolathálóján keresztül = Irodalomtörténeti Közlemények, 2006/6, 650-676.

${ }^{66}$ Wittmann, Reinhard, Az olvasás forradalma a 18. század végén? = Az olvasás kultúrtörténete a nyugati világban, szerk. Guglielmo Cavallo, Roger Chartier, ford. Sajó Tamás, Bp., Balassi Kiadó, 2000, 337. 
tív szövegtípusok látványosan hátat fordítanak a korábbi, a szövegek paratextusaiban mintázódó közönségképzetek, ideologikus beszédmódok konszenzuális alkalmazásának, egyértelmúvé téve, hogy e gyakorlat, a széles értelemben vett nyilvánosságtól paradox módon elzárt retorika önmagában kielégítetlenül hagy számos, a kötet sikeressé tételéhez szükséges feltételt. Világos, hogy ezt követően a kiadók már tudatosan számot vetnek a hírlapok nyilvánosságteremtő és -közvetítő szerepével, melynek következményeként fokozatosan diszkurzív tevékenységgé alakul a románok hirdetésének gyakorlata. Dinamikus térnyerésük pedig a habermasi polgári nyilvánosság kialakulása felé mutat. A két elkülönített forráscsoport vizsgálatából az a konzekvencia szürhető le, hogy a korszak kiadói számára az olvasóközönség megközelítésében és megnyerésében a konkrét gyakorlati tevékenységek kerülnek domináns pozícióba, egyértelművé téve, hogy pusztán ideologikus toposzokat felvonultató szólamokkal már nem tehetö sikeressé egy deklaráltan gazdasági szemlélet erőterében formálódó vállalkozás.

\section{BÉRES, NORBERT}

\section{'Roman - et quoi de meilleur qu'un Roman' - stratégies de popularisation du genre}

L'auteur de la présente étude se propose de reconstruire les pratiques éditoriales, publicitaires et de diffusion des collections de roman aux $18^{\mathrm{e}}-19^{\mathrm{e}}$ siècles. Il est notoire que le tournant du siècle est la période de la conquête de la prose en langue hongroise et de l'essor quantitatif du roman. L'accroissement spectaculaire du nombre des romans publiés a rendu nécessaire l'établissement d'un régime de financement et de diffusion, ainsi que la mise en place de techniques publicitaires efficaces. Les types de textes correspondant à cette logique - le 'rapport', 'l'avis', la 'recension' et enfin le 'compte-rendu' - illustrent la sortie de l'activité publicitaire de la sphère privée: les attraits des livres déjà publiés (ou en cours de publication) y sont détaillés pour capter l'attention d'un public très large. Il est indiscutable que la diffusion et la commercialisation de cette marchandise qu'est le livre devient une préoccupation majeure des éditeurs de l'époque. Les annonces et les comptes-rendus parus dans les périodiques ont non seulement contribué à la diffusion plus efficace des produits, mais ils ont également créé la possibilité d'un discours critique littéraire. Afin de pouvoir interpréter dans son contexte la promotion de la prose et le triomphe du roman au tournant des $18^{\mathrm{e}}-19^{\mathrm{e}}$ siècles, il convient de se servir des méthodes que nous fournit la sociologie de la littérature.

Keywords: 19 th century, History of publishing, Press History, Prose, Book series 